\title{
Optical Recording of Calcium and Voltage Transients Following Impulses in Cell Bodies and Processes of Identified Leech Neurons in Culture
}

\author{
W. N. Ross, ${ }^{1}$ H. Arechiga, ${ }^{1, a}$ and J. G. Nicholls ${ }^{2}$ \\ 'Department of Physiology, New York Medical College, Valhalla, New York 10595, and PPharmacology Department, \\ Biocenter, Basel, Switzerland 4056
}

Optical methods were used to examine the spread of electrical potentials and the distribution and time course of calcium transients in individual identified nerve cells isolated from the leech. A photodiode array detected voltage transients by measuring absorbance changes of cells stained with the voltage-sensitive dye RH155 added to the bath. Calcium transients were recorded by measuring absorbance changes of the dye arsenazo III, which had been injected into the cells. In addition, Lucifer yellow was injected to outline the soma and processes. Calcium changes resulting from individual action potentials were recorded from $N, P$, and Retzius cells without averaging. Signals from $T$ cells and anterior pagoda (AP) cells were weaker but could be detected with averaging. These results are in accord with previous studies on calcium contributions to action potentials in these cells. For all cells, larger or wider action potentials gave bigger signals. Calcium changes from each of a train of action potentials were of equal amplitude, showing no sign of facilitation. Calcium transients from Retzius cells that had formed chemical synapses with $P$ cells had properties similar to those of isolated cells. We were also able to detect responses from prolonged subthreshold depolarizations to $-40 \mathrm{mV}$ from a hyperpolarized membrane potential (-65 $\mathrm{mV})$. These signals rose throughout the duration of the pulse (1-2 sec).

With the photodiode array we mapped the distribution of the calcium signals. The amplitudes from each pixel are proportional to the amount of calcium entering that element in response to the stimulating pulse, if the simplifying assumption is made that the calcium buffering of the cytoplasm is uniform throughout the cell. The largest signals were detected over the axon stump left from the cell isolation procedure. Large signals were also detected from the soma. Weak signals were detected from the processes of some

\footnotetext{
Received Oct. 1, 1986; revised May 8, 1987; accepted May 20, 1987.

We thank Professor Itzhack Parnas, Hebrew University, Jerusalem, Israel, for his encouragement and support during the early stages of our experiments, Ms. Hedi Neiderer for excellent technical assistance throughout the course of our work, and Larry Cohen for comments on the manuscript. This work was supported in part by USPHS Grant NS 016295 and the Irma T. Hirschl Foundation (W.N.R.), and the Swiss National Fund and the U.S. Navy (J.G.N.). W.N.R. was a Fogarty International Fellow during part of this project. H.A. received support from Hoffman La Roche Foundation.

Correspondence should be addressed to W. N. Ross at the above address

Permanent address: Depto. de Fisiologia, Biofisica y Neurociencias, CINVESTAV-IPN, 07000 México, D.F.

Copyright (C) 1987 Society for Neuroscience $0270-6474 / 87 / 123877-11 \$ 02.00 / 0$
}

cells. From many Retzius cells, no signals at all were detected from the newly formed processes.

Using the photodiode array, we also recorded voltage transients from the same cells. Signals were recorded from all over the arborization of the neuron, with no obvious variation in time course, showing that the entire cell, including fine slender processes and broad growth cones, was essentially isopotential. Combining these observations with the measured distribution of calcium transients in the same cell suggests that the density of calcium channels in most cells is less in the outgrowing processes than in the soma or axon stump.

For the analysis of problems concerned with signaling and plasticity in which calcium entry plays a key role, optical recording techniques using appropriate indicator dyes can provide a sensitive assay with high temporal and spatial resolution. When combined with electrical recordings, it is possible to estimate the time course of calcium accumulation and its decline in different regions of a neuron following action potentials (Ross et al., 1986). The aim of the present experiments has been to measure calcium transients in identified leech nerve cells having distinctive membrane properties in tissue culture.

These are the sensory $\mathrm{T}, \mathrm{P}$, and $\mathrm{N}$ cells, the Retzius cells, and the anterior pagoda (AP) cells, which can be removed one by one from the CNS of the leech and kept alive for days or weeks. Each of these cells continues to give distinctive action potentials, retains its membrane properties, sprouts with a characteristic arborization, and forms a set of specific chemical or electrical synaptic connections in culture (Fuchs et al., 1981, 1982). For example, Retzius cells have overshooting action potentials, broad, flat growth cones [when grown on concanavalin A (Con A)], and make chemical synapses on P cells. At those synapses, where 5-HT is the transmitter (Henderson, 1983), facilitation of transmission, with increasing quanta liberated per impulse, occurs during brief trains (Henderson et al., 1983; Dietzel et al., 1986). Modulation of release occurs with prolonged changes in resting potential. In principle, isolated cells in a dish could provide favorable preparations in which one could directly correlate impulse activity with calcium entry into different regions of the neuron, including sites of transmitter release.

As a first step, we approached the following problems: (1) Are there reliable optical signals that correspond to an increase in intracellular calcium following action potentials in leech neurons in culture? Can the method resolve calcium entry with a single impulse; and do different types of neurons, with their 
$\begin{array}{lll}P \text { cell } & N \text { cell } & \text { Retzius cell }\end{array}$

Figure 1. Calcium transients from individual action potentials recorded without averaging by a single photodiode element positioned over the soma of P (6 d), N (6 d), and Retzius (5 d) cells in culture. The absorbance signals have been digitally filtered with a cutoff frequency of $60 \mathrm{~Hz}$. For the Rezius cell, the unfiltered signal, sampled at $500 \mathrm{~Hz}$, is also shown. The scale for the calcium signal in this and other figures is arbitrary and is proportional to the change in absorbance at $660 \mathrm{~nm}$. The top traces are the electrically recorded action potentials, using a bridge electrometer.

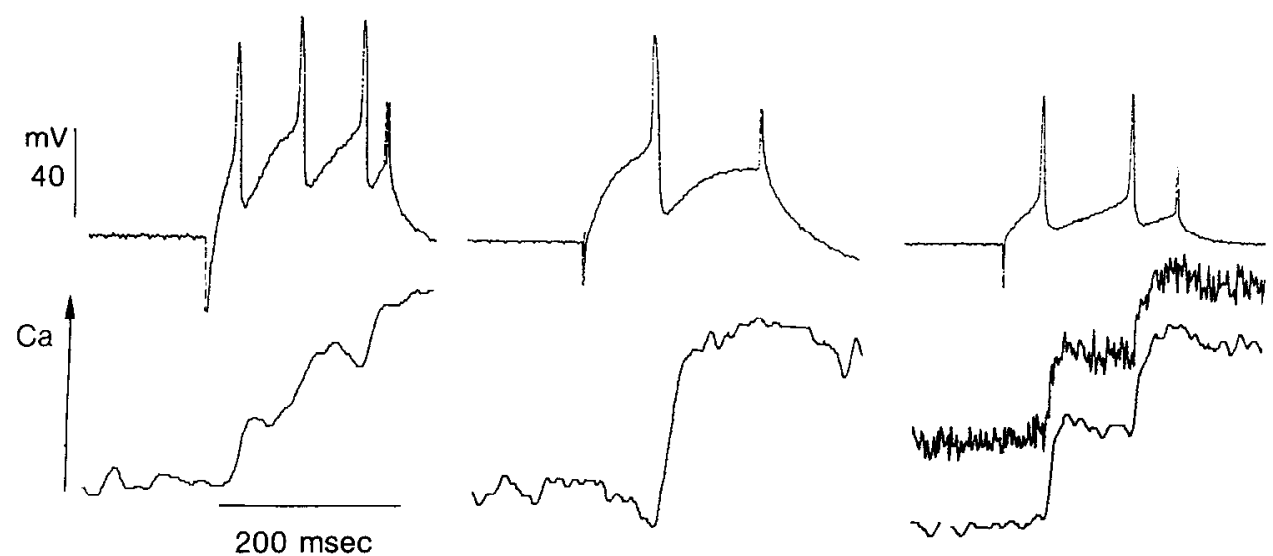

characteristic spike amplitudes and calcium-dependent conductances, exhibit different optical signals? (2) With brief trains of impulses at frequencies known to produce facilitation, is calcium entry constant per impulse or does it increase? (This has a bearing on the analysis of facilitation at synapses, where indirect evidence at present suggests that it is residual calcium, rather than facilitated entry, that is the key factor.) (3) Is calcium entry following action potentials similar in the cell body, the initial segment, the newly grown processes, and the growth cones? Or are there distinctive regional variations corresponding to variations in the density of calcium channels (e.g., Stockbridge and Ross, 1984; Bolsover and Spector, 1986)?

In approaching these questions, we found it important to confirm that voltage signals recorded in the soma were also spreading into the processes and growth cones of these cells. With the same photodiode array used to record the calcium signals, we could also record potential changes from all over the cell by detecting absorbance changes of bath-applied, voltagesensitive dyes (Salzberg, 1983; Grinvald, 1985; Cohen and Lesher, 1986). The combination of the 2 optical techniques proved to be a powerful method for examining the regional properties of these neurons.

Some of these results have appeared in abstract form (Arechiga et al., 1985; Nicholls et al., 1986).

\section{Materials and Methods}

Removal of leech neurons and culture procedures. The techniques for isolating and culturing leech neurons have been described elsewhere (Chiquet and Acklin, 1986; Dietzel et al., 1986). In brief, ganglia from Hirudo medicinalis were removed, the capsules opened, and neurons exposed to enzyme ( $2 \mathrm{mg} / \mathrm{ml}$; Collagenase/Dispase; Boehringer, Mannheim). After $45 \mathrm{~min}$ in enzyme, identified cells were sucked out, one by one, using a mouth pipette. After washing in Leibowitz 15 medium with $2 \%$ fetal calf serum and gentamicin, they were plated on the covers of culture dishes (Falcon 3001) coated with Con A $(2 \mathrm{mg} / \mathrm{ml}$, dried and washed) in the same medium (Chiquet and Acklin, 1986). Isolated neurons sprout extensively and rapidly within $24 \mathrm{hr}$ in these conditions. These cells were used in most experiments. When 2 cells were cocultured to form synaptic connections, the substrate was polylysine. In this condition cells adhere but sprout little in the first $5 \mathrm{~d}$.

For the experiments described in this paper, we selected cells that had a minimum of vacuoles and membrane blebs, with growth cones of normal appearance. These cells had characteristic action potentials and high input impedance.

Electrophysiology. Recordings were made using a conventional bridge electrometer. The headstages were mounted on hydraulic micromanip- ulators (Narishige MO-103) fixed to the stage of the microscope. This allowed changes of the field of view or focus without losing the impalement. For most experiments, the calcium content of normal leech saline was raised to $10 \mathrm{~mm}$ (Fuchs et al., 1982) to enhance synaptic transmission, improve recording stability, and increase the size of the calcium signals. In some experiments $\mathrm{CdCl}_{2}$ was added to this saline to a concentration of $1 \mathrm{~mm}$. All experiments were performed at room temperature $\left(18-21^{\circ} \mathrm{C}\right)$.

Optical signals. Arsenazo III (Sigma; 8891) was prepared as a stock solution of $75 \mathrm{~mm}$ dye in distilled water. Lucifer yellow (Sigma; 0259) was prepared as a $100 \mathrm{~mm}$ stock. These 2 solutions were then mixed in a ratio of about 3:1. Electrode tips (Glass Co. of America; 1011L) were filled by capillary action and the shanks backfilled with $3 \mathrm{M} \mathrm{KCl}$. In choosing the dye ratio, we attempted to maximize the amount of arsenazo III in order to detect small calcium changes while injecting sufficient Lucifer dye to outline the cell. After impaling a cell, both dyes were ionophoresed into the cytoplasm with negative current pulses or constant current. When the soma was pink we stopped injection and waited about $10 \mathrm{~min}$ for the dyes to diffuse into the processes and growth cones. On the basis of our experience with other preparations (Ross et al., 1986) and the full penetration of the coinjected Lucifer yellow, we have found that this is enough time for arsenazo III to penetrate fully into these cells.

Calcium changes were detected by monitoring the change in absorbance at $660 \pm 15 \mathrm{~nm}$ of cells that had been filled with arsenazo III to a concentration of about $0.3 \mathrm{~mm}$. The apparatus for simultaneously recording these absorbance changes at many positions has been described previously (Ross et al., 1986). For these experiments we used a $40 \times$ water-immersion lens (Zeiss 5232814 ), which made each photodiode element record from an area of $40 \times 40 \mu \mathrm{m}^{2}$. In one experiment (Fig. 14) in which a $25 \times$ water-immersion lens (Leitz 519706) was used, each element detected an area of $64 \times 64 \mu \mathrm{m}^{2}$. The signal from each photodetector was amplified and low-pass-filtered, with a time constant of $10 \mathrm{msec}$. After subtraction of a constant level, the signal was further amplificd and digitized, with samples taken every 2 msec. Many records in this paper were smoothed with a digital filter (Hamming, 1977; Ross and Krauthamer, 1984). Figure 1 shows that this procedure did not distort the calcium signals.

For optical measurement of voltage changes, the dye RH155 (Grinvald et al., 1982; available from Nippon Kenkyusho, Okayama, Japan as dye NK 3041) was prepared as a solution of $1 \mathrm{mg} / \mathrm{ml}$ dye in leech saline. Fresh solutions were made for each experiment. The cells were dyed for about $15 \mathrm{~min}$ and then washed with high-Ca saline. Voltage signals were measured as absorbance changes at $720 \pm 15 \mathrm{~nm}$. The same apparatus was used as for the calcium measurements, except that the low-pass filter had a time constant of $0.1 \mathrm{msec}$ and records were digitized at a sample rate of $2 \mathrm{kHz}$.

In some experiments both calcium and potential measurements were made on the same cell; arsenazo III and Lucifer yellow were injected into the cell and the calcium transients recorded. Then the cell was stained with the voltage-sensitive dye and the voltage transients were recorded. This sequence was necessary because RH155 is sensitive to 


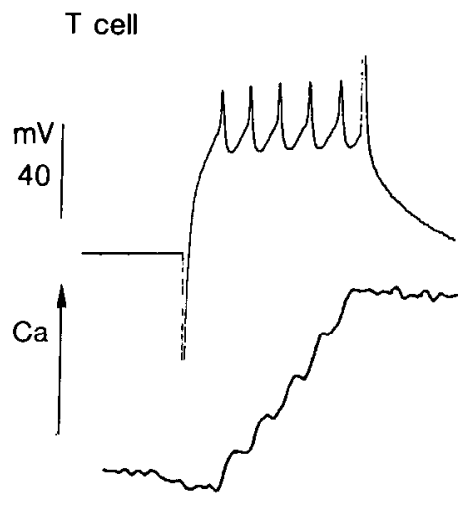

AP cell

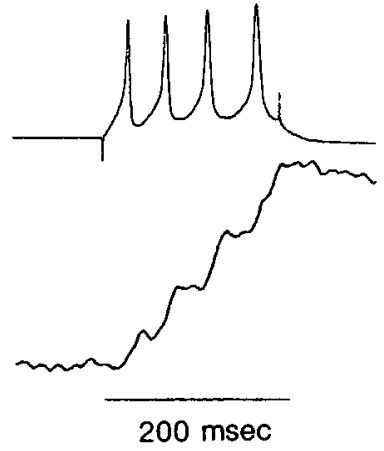

Figure 2. Calcium transients from individual action potentials from $T$ and AP cells detected by a single photodiode element positioned over the soma. For the T cell, 200 sweeps were averaged and the filter cutoff frequency was $70 \mathrm{~Hz}$; for the AP cell, 150 sweeps were averaged and the cutoff frequency was $60 \mathrm{~Hz}$. Note the constant increment in amplitude for the repetitive $T$ cell action potentials and the increasing amplitudes following the widening action potentials of the AP cell.

voltage changes at $660 \mathrm{~nm}$, the wavelength for calcium measurements, but arsenazo III does not respond at $720 \mathrm{~nm}$, where the voltage measurements were made.

At the conclusion of the experiment, the cell shape was determined by exciting the fluorescence of Lucifer yellow with a mercury lamp and selected filters (Stewart, 1978). Photographs of the cell were then used to map the optical signals onto the appropriate parts of the cell (Ross and Krauthamer, 1984).

\section{Results}

After injection of arsenazo III, the neuronal cell body became pink and remained so for the rest of the experiment. Damaged cells had a bluish color, reflecting a high calcium level, and were not used. The resting and action potentials of $\mathrm{T}, \mathrm{P}, \mathrm{N}$, Retzius, and AP cells were not changed by the dye. Following impulses in each of the cells, clear, distinctive step increases in absorbance were recorded (Figs. 1, 2). The changes in N, P, and Retzius cells were large enough to be detected in a single trial. Under similar conditions, signals from $\mathrm{T}$ and AP cells could not be detected in one trial but were resolved after averaging.

No signals were detected above noise level without arsenazo III in the cells. The wavelength dependence of the signals was characteristic of the calcium-dye reaction, i.e., there was a strong increase in absorbance at $660 \mathrm{~nm}$, a small decrease at $540 \mathrm{~nm}$, and little change at $570 \mathrm{~nm} . \mathrm{CdCl}_{2}(1 \mathrm{~mm})$ blocked the absorbance signals but not the action potentials (Fig. 3). When external calcium was increased from 1.8 to $10 \mathrm{~mm}$, the optical transients increased in magnitude, while the action potentials in these cells showed little or no discernible change (Jansen and Nicholls, 1973). These results, taken together, show that the absorbance transients recorded with arsenazo III represent increases in intracellular calcium due to activity-dependent entry of calcium from the external medium.

The latency from the peak of the action potential to the onset of the calcium signal was less than $5 \mathrm{msec}$, and the time to peak usually less than $15 \mathrm{msec}$. These times were certainly fast enough to resolve transients from individual action potentials (Figs. 1, 2). The time course for the decay of the absorbance signal from the soma of a typical cell was not an exponential but often returned to one-third of its peak value in about $0.25 \mathrm{sec}$, somcwhat faster than has been recorded from other invertebrate neurons in intact ganglia (Ross et al., 1986). This value should not be interpreted as a true measure of the recovery time constant of calcium in the cells, since the dye acts as a buffer (Gorman and Thomas, 1980) and slows the recovery process. However, it can be interpreted as an upper limit on the recovery time.

Bccausc of the difficulty of accurately knowing the stoichiometry and reaction kinetics of the calcium-dye reaction (Baylor et al., 1982) and because the pathlength through the cell (especially in the process) is difficult to determine, we could not make an estimate of the resting calcium level or the magnitude of the calcium change in our experiments. However, it has been

Retzius cell
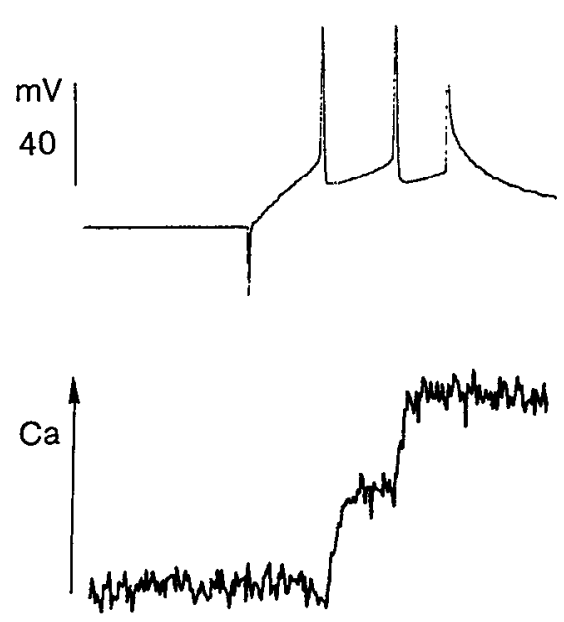

$200 \mathrm{msec}$
$\mathrm{CdCl}_{2} 1 \mathrm{mM}$
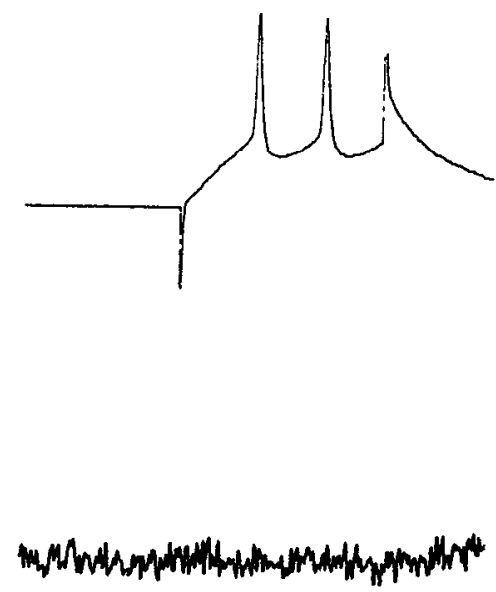

Figure 3. Effect of cadmium ions on calcium transients from the soma of a Retzius cell ( $6 \mathrm{~d})$. The calcium signals are the average of 25 trials; the electrical record is from one of these trials. The calcium scale is arbitrary but the same for each panel. In the presence of $1 \mathrm{~mm}$ $\mathrm{CdCl}_{2}$, calcium entry is abolished while the action potential is unchanged. 


\section{Retzius cell}

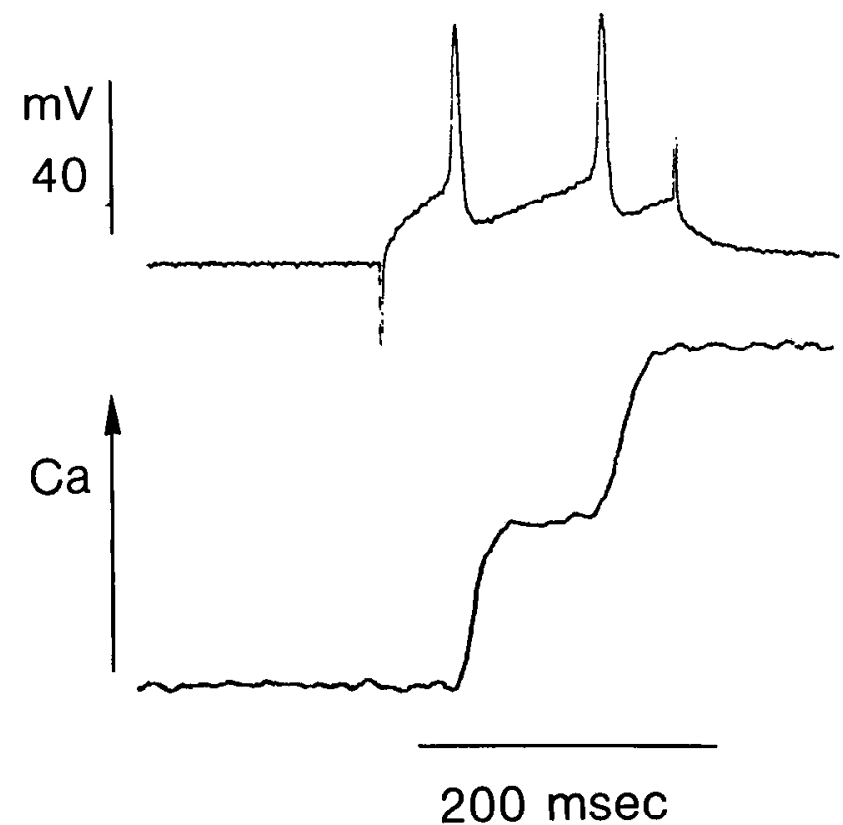

Figure 4. Calcium transients following paired impulses from the soma of a Retzius cell ( $5 \mathrm{~d} ; 25$ optical sweeps averaged; filter frequency, 60 $\mathrm{Hz}$ ). The steps of calcium entry are similar for each action potential, with no evidence for facilitation. The slightly slower rise time of the second transient is due to the jitter in the firing time of the second action potential. However, this jitter is much smaller than the recovery time of the transient, so there is no effect on the amplitude. For this experiment, each trial was followed by a pause of $30 \mathrm{sec}$ to mimic stimulus parameters used during tests for facilitation.

determined in a variety of preparations (e.g., Miledi and Parker, 1981; Augustine et al., 1985) that the amplitude of the absorbance change is proportional to the amount of calcium entering the cytoplasm as long as the decay time is slow compared to the rise time of the transient. This condition was met in our experiments. The constant of proportionality in this linear re- lationship depends on the buffering power of the cytoplasm and the amount of binding of ions and other intracellular constituents to arsenazo III. Therefore, the signals from different pixels can be directly compared only by assuming that these properties are the same in all parts of the cell.

\section{Effects of twin pulses and holding potential on $\mathrm{Ca}^{2+}$ transients}

When Retzius or $\mathrm{N}$ cells form chemical synapses on their targets in culture ( $\mathrm{P}$ or L cells, respectively; see Fuchs et al., 1981, 1982), facilitation occurs with pairs or trains of action potentials. Successive action potentials cause the release of increased numbers of quanta (Henderson et al., 1983). By contrast, in the present experiments calcium transients with successive impulses did not change in amplitude, as shown in Figure 4. This constancy of step size was observed in both normal $(1.8 \mathrm{~mm})$ and raised (10 mM) calcium. With a single trial (involving no repetition or gradual depression of release), the signal-to-noise ratio was smaller, but the results (Fig. 1) resembled those seen after averaging. On the other hand, bigger or wider action potentials did let in more calcium than did normal action potentials, as shown in Figure 2. In the AP cell, each succeeding action potential in the train was wider than the previous one, and the increment in absorbance was correspondingly greater (see also Stinnakre and Tauc, 1973).

Changes in steady holding level had no obvious effect on calcium transients. Figure 5 shows a $\mathrm{P}$ cell in which action potentials were initiated from a normal resting potential of -42 $\mathrm{mV}$. When the cell was hyperpolarized to $-56 \mathrm{mV}$, action potentials were again followed by calcium transients of similar amplitude. Figure 6 shows the same result in a different way. In this case the $\mathbf{P}$ cell was stimulated to fire 3 action potentials. During the time shown by the bar, a steady hyperpolarizing current was applied that made the second action potential begin from about a $10-15 \mathrm{mV}$ lower potential. But all 3 calcium transients had similar amplitudes.

Changes in holding potential did, however, influence the slow buildup or decline in intracellular calcium. It is known of leech neurons in ganglia, as well as in culture, that small changes in resting potential of the order of $10-20 \mathrm{mV}$ can modulate steady
Figure 5. Hyperpolarization of a $P$ cell ( 7 d) had no effect on the calcium entry recorded following an impulse. Average of 25 trials. The scale of the calcium signals is arbitrary but is the same for each panel. In the second panel, the cell was hyperpolarized (arrow) with a steady current through the recording electrode.
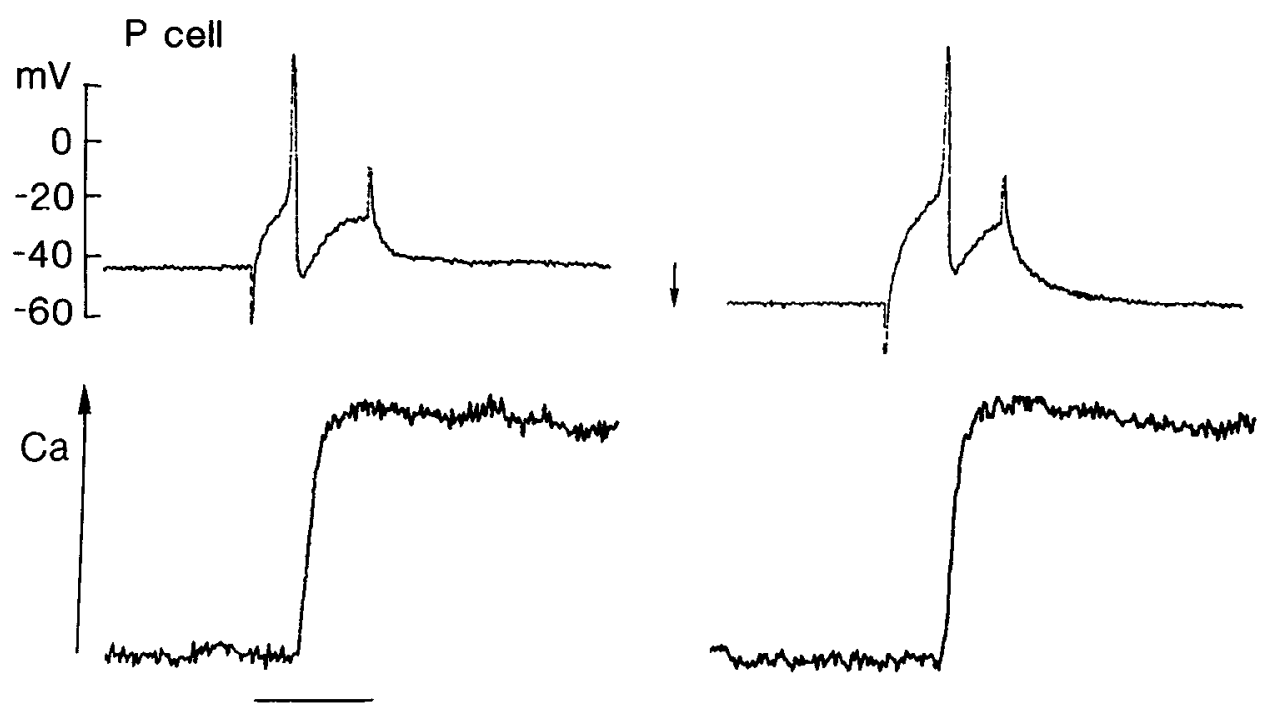

$100 \mathrm{msec}$ 

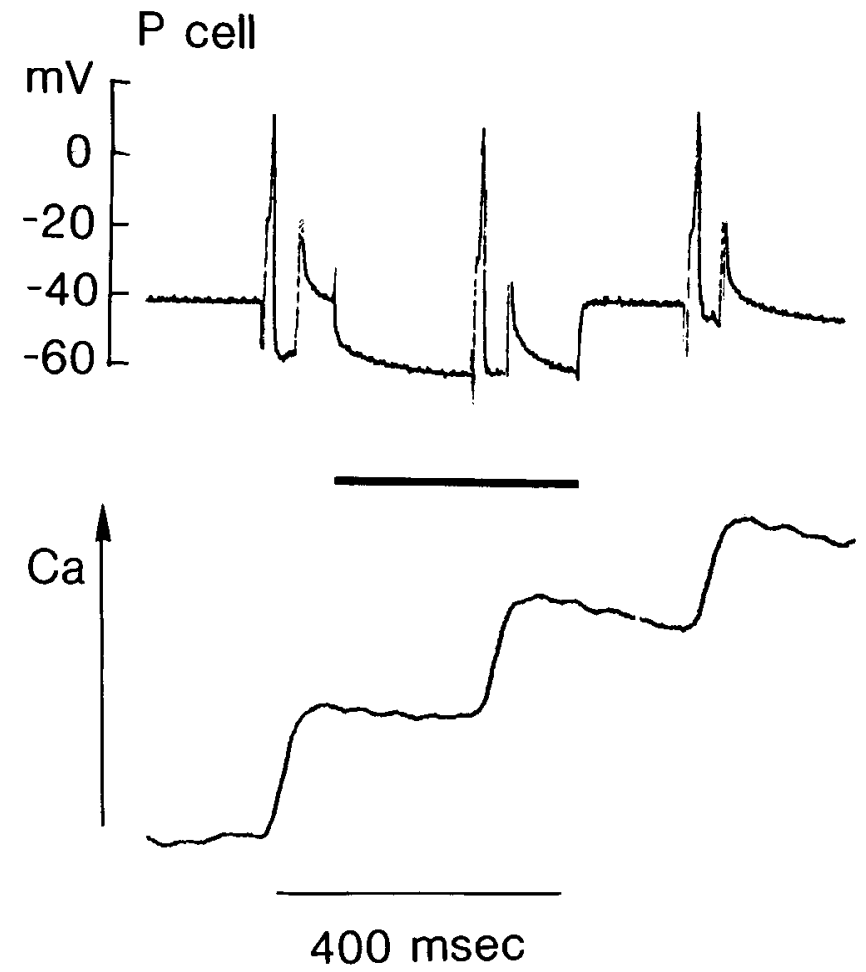

Figure 6. Step hyperpolarization of a P cell ( $7 \mathrm{~d})$ had no effect on the amplitude of calcium transients following an impulse. For the $350 \mathrm{msec}$ indicated by the bar, the cell was hyperpolarized through the bridge circuit of the electrometer. Average of 10 trials. Filter cutoff frequency, $15 \mathrm{~Hz}$.

transmitter release and dramatically change the release evoked by action potentials (Thompson and Stent, 1976; Fuchs et al., 1982; Dietzel et al., 1986). Figure $7 B$ shows the effect of depolarizing a cultured Retzius cell with a current pulse lasting 1 sec. After a delay, there is a steady buildup in the level of calcium, which begins to decline after the pulse is turned off. Comparing this response with the spike-evoked signal shows that only part of this delay might be accounted for by the rise time of the voltage response. Similar delays are observed in the onset of transmitter release following subthreshold-maintained depolarization of Retzius cells (Dietzel et al., 1986, Fig. 2).
Hyperpolarizing pulses from about $-60 \mathrm{mV}$ caused no change in calcium. Figure $7 A$ shows transients recorded from the same cell as are the slow signals in Figure $7 B$. In this experiment each impulse let in about $10 \%$ more calcium than the entire $1 \mathrm{sec}$ subthreshold pulse. Similar signals were recorded from Retzius cells in the intact ganglion, showing that the isolation and culturing procedures did not cause the appearance of these slow signals.

\section{Calcium signals in presynaptic neurons}

One of the main aims of these experiments is to understand the role of intracellular calcium in the release and modulation of neurotransmitters. It was therefore of importance to test whether the kinds of signals we recorded from isolated neurons also occurred in cells that had made chemical synapses with other cells. Retzius and $P$ cells, which have previously been shown to form serotonergic synapses in culture (Fuchs et al., 1981, 1982; Henderson, 1983), were cultured side by side on polylysine. Both cells were impaled with microelectrodes and the Retzius cell filled with arsenazo III. When the Retzius cell was stimulated, synaptic potentials were recorded in the $\mathbf{P}$ cell, and calcium transients were recorded from all positions on the Retzius cell, one of which is shown in Figure 8. The calcium transients were qualitatively the same as those recorded from isolated Retzius cells. In these paired cells we did not examine calcium changes corresponding to long subthreshold pulses (Fig. $7 B$ ), although it is known that this kind of stimulation will modulate the release of transmitter (Dietzel et al., 1986).

\section{Distribution of calcium signals in leech neurons}

$\mathrm{N}, \mathrm{P}, \mathrm{T}$, Retzius, and AP cells plated on Con A grew sprouts within a day, cach cell type having its own distinctive branching pattern (Chiquet and Acklin, 1986). After the cell body and initial segment had attached to the substrate, new sprouts grew out from the initial segment and sometimes from the soma. The first processes tended to be flat, with broad growth cones (especially from Retzius cells), but within a few days the processes fasciculated.

We examined the distribution of calcium signals in these cells using the photodiode array. Since calcium diffuses slowly in cytoplasm $\left(D \cong 3 \times 10^{-6} \mathrm{~cm}^{2} / \mathrm{sec}\right.$; Blaustein and Hodgkin, 1969) and the time to peak of the signals was about the same all over

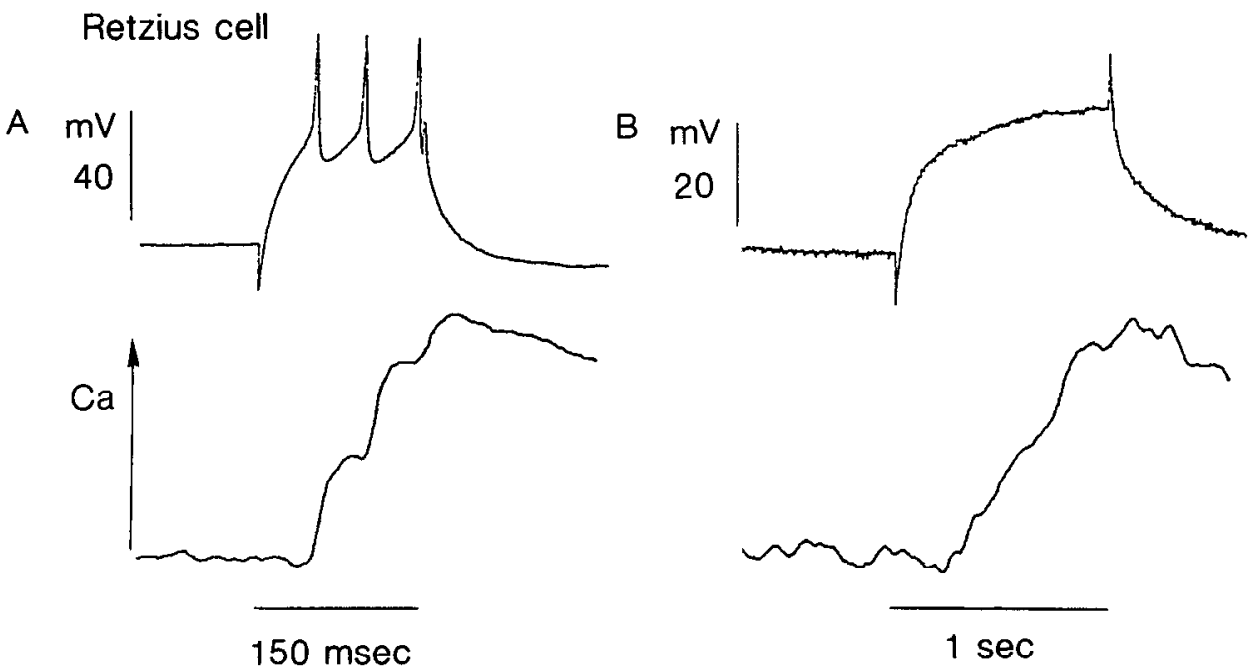

Figure 7. Impulse-mediated and subthreshold calcium entry recorded from a Retzius cell $(6 \mathrm{~d}) . A$, The stimulus was strong enough to evoke a train of action potentials. The amplitude of the last transient is smaller than the other 2 because the last action potential occasionally did not fire. Only one electrical trial is shown. The calcium signal is the average of 25 sweeps, $B$, The stimulus was below threshold but a signal was still detected. Resting potential, $-65 \mathrm{mV}$. Average of 25 sweeps. The calcium scales in both panels are not the same. Cutoff frequency $60 \mathrm{~Hz}$. 


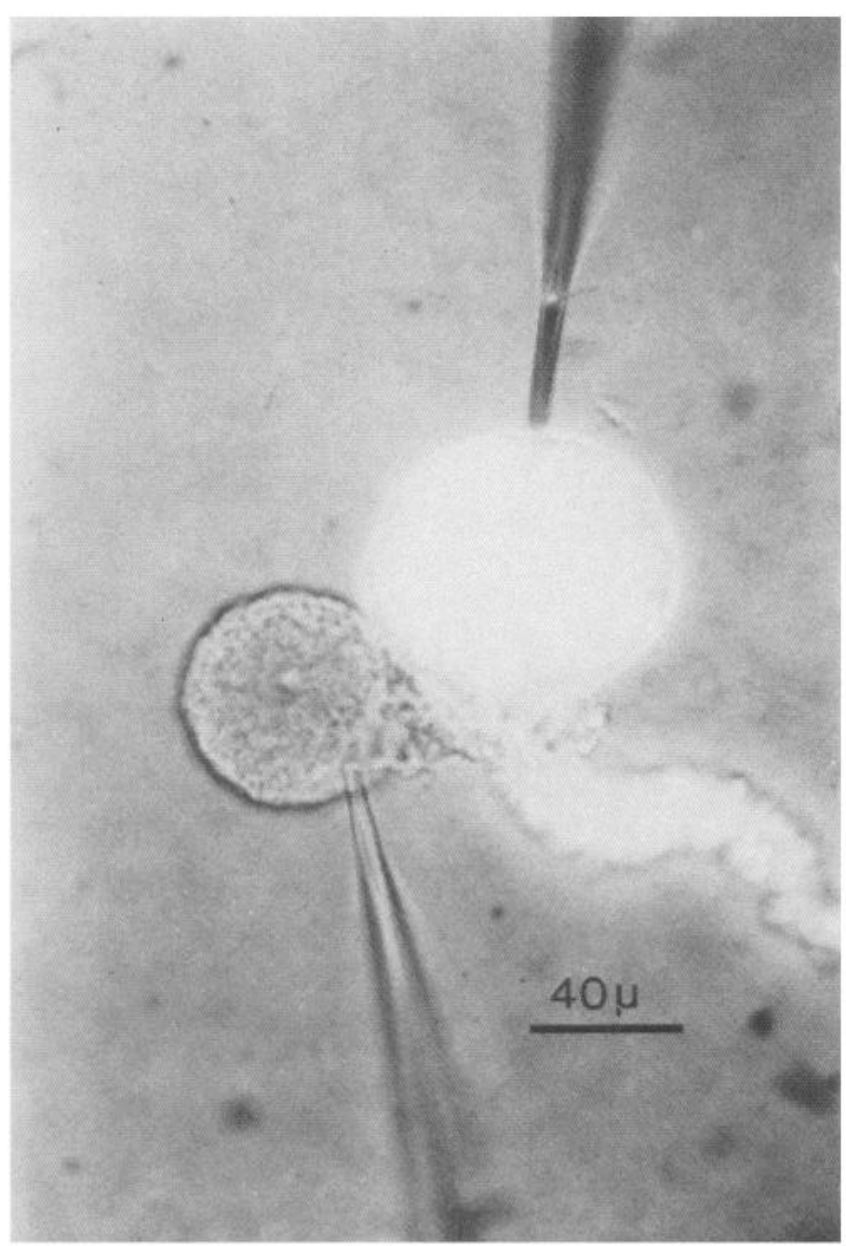

the cell, the signals detected by each photodiode element were due to calcium entering through the membrane in the area covered by each pixel. If the membrane is uniformly excited (see below) and the buffering power of the cytoplasm is constant under the membrane in all parts of the cell, then the signal size is proportional to the number of calcium channels within each pixel (see Discussion).

Figure 9 shows a typical montage of calcium signals, as recorded from a Retzius cell when it was stimulated by an intracellular microelectrode. The distribution of traces over this and almost every other Retzius cell showed strong signals from the soma and axon stump (D) regions and no signal from the newly growing processes. The AP cell distribution was similar, except that in some cells there were weak signals over the new processes (see Fig. 13). The $\mathrm{N}$ cell (Fig. 10) had significantly stronger signals in the processes. This last observation confirms that arsenazo III penetrated into the processes.

The observation of weak or no calcium signals from the processes of Retzius or AP cells could result from a failure of the somatically stimulated action potential to spread to the growth cones. If this were so, the voltage-dependent calcium channels, through which the calcium presumably enters, would fail to open. Previous observations suggested that this was unlikely and that, in fact, the cells were probably isopotential. For example, the high input impedance of these cultured cells was used by I. Parnas and I. Segev (unpublished observations) to calculate that the potential decrement along even 1- $\mu$ m-diameter pro-
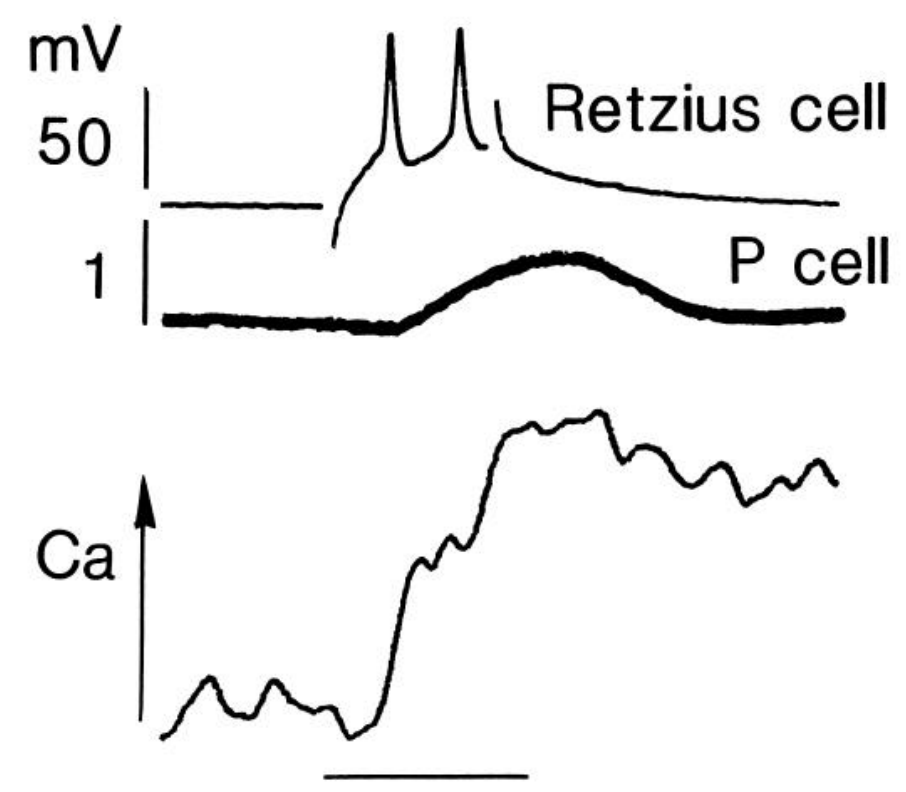

$100 \mathrm{msec}$

\begin{abstract}
Figure 8. Calcium transients in a Retzius cell that had formed a chemical synapse upon a $P$ cell $(10 \mathrm{~d})$. Action potentials in the Retzius cell gave rise to typical calcium entry signals ( 30 trials) and evoked synaptic potentials in the $\mathrm{P}$ cell. The calcium signal was filtered with a cutoff frequency of $60 \mathrm{~Hz}$. In the photograph the Retzius cell is brighter because of the fluorescence of Lucifer yellow, which was coinjected with arsenazo III. Note that the cells that are cultured on polylysine have few processes.
\end{abstract}

cesses would be insignificant. Also, Pellegrino and Simonneau (1984) showed that with an intracellular electrode in the soma, the reversal potential for ionophoretically applied ACh was the same whether the neurotransmitter was applied to the soma or to the tip of a growing process. Using voltage-sensitive dyes, we could test this conclusion directly. Figure 11 shows voltagesensitive dye recordings made simultaneously from many regions of a Retzius cell when the neuron was stimulated by an electrode in the cell body. The inset shows optical recordings from the soma and the tip of the process, compared to the electrical recordings made with the bridge electrometer. All 3 records look essentially the same, except that the optical traces do not have the stimulus artifact. This shows that both the slow potential from the stimulus and the action potential are undistorted in the processes, confirming that the cell is isopotential.

Another possible explanation for the dearth of calcium signals from the processes is that the membrane area under the photodiode is so small that very little calcium would enter the cytoplasm in that region even if the current density there were about the same as that in the soma. The Lucifer yellow fills of the cell (e.g., Fig. 9) suggested that this was not true. But it was useful to have a more quantitative measure of relative membrane area. If we assume that the voltage-sensitive dye stains the membrane of the cell uniformly, then the amplitude of the optically recorded changes in absorbance made with these dyes should be proportional to the stained area within each pixel, since we have already established that the cell is isopotential. 


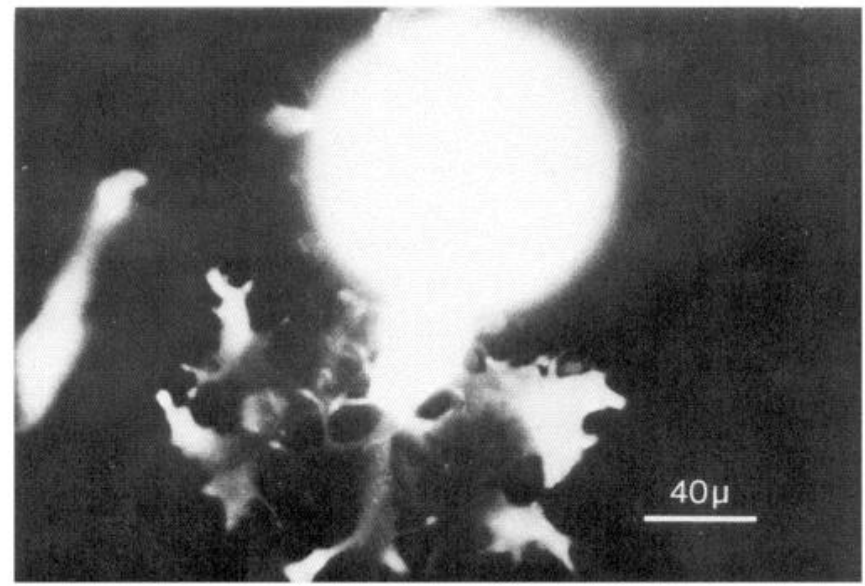

Figure 9. Changes in absorbance at $660 \mathrm{~nm}$ for 48 positions over a field containing a cultured Retzius cell $(2 \mathrm{~d})$ filled with arsenazo III. Each trace shows the absorbance change during $500 \mathrm{msec}$ in a field $40 \times 40 \mu \mathrm{m}^{2}$ (filled area, bottom right). The cell was stimulated to fire 3 action potentials (bar at bottom). Average of 200 sweeps; signals lowpass-filtered at $60 \mathrm{~Hz}$. The vertical scale is arbitrary but the same for all traces. The photograph shows the Lucifer yellow fluorescence from which the cell was drawn. Large absorbance changes were detected over the soma and initial segment $(D)$ but not over growth cones.

Figure 11 shows that clearly detectable voltage signals were obtained from the processes of a Retzius cell; however, no calcium signals were detected from the processes of a similar cell (Fig. 9).

This kind of comparison was more compelling in an experiment in which we recorded both the distributon of voltage transients and the distribution of calcium transients from the same cell (Figs. 12, 13). The shapes of the optically recorded
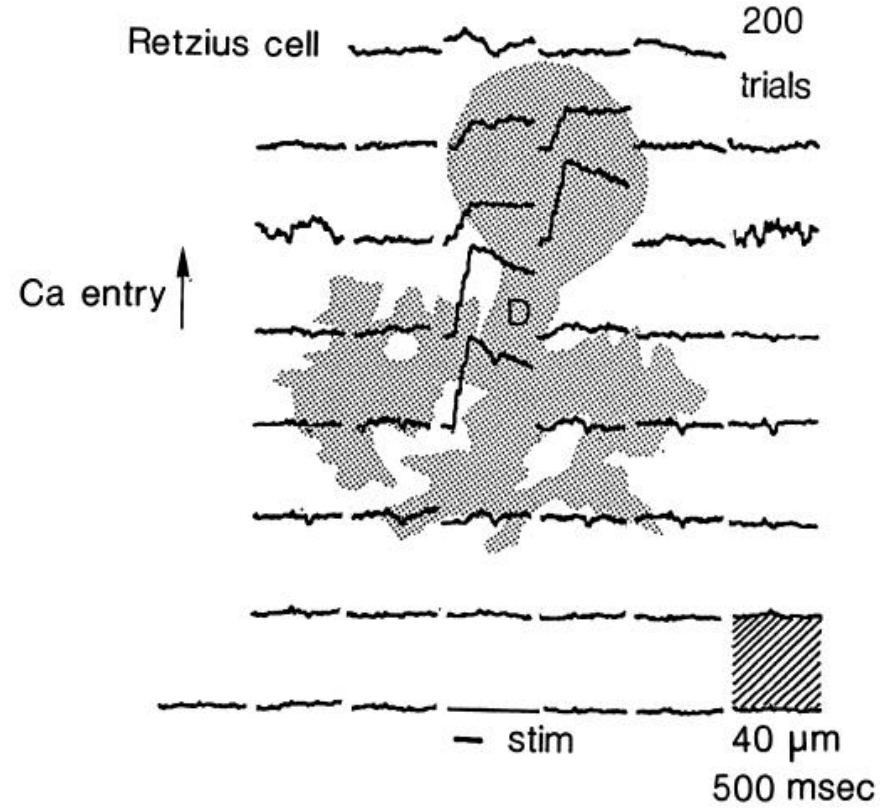

voltage transients were the same all over the cell, suggesting that the cell was isopotential. Yet the magnitude of the voltage signals in the processes was larger than the magnitude of the calcium signals in this region when both were normalized to the same size in the soma. Specifically, we calculated the magnitudes of each kind of signal for the 12 pixels over the soma and the 13 pixels over the processes. When the sum of the somatic signals for each region was normalized to 1.0 , the ratio of the calcium signals to the voltage signals in the processes was 0.55 , suggesting

\section{$\mathrm{N}$ cell}

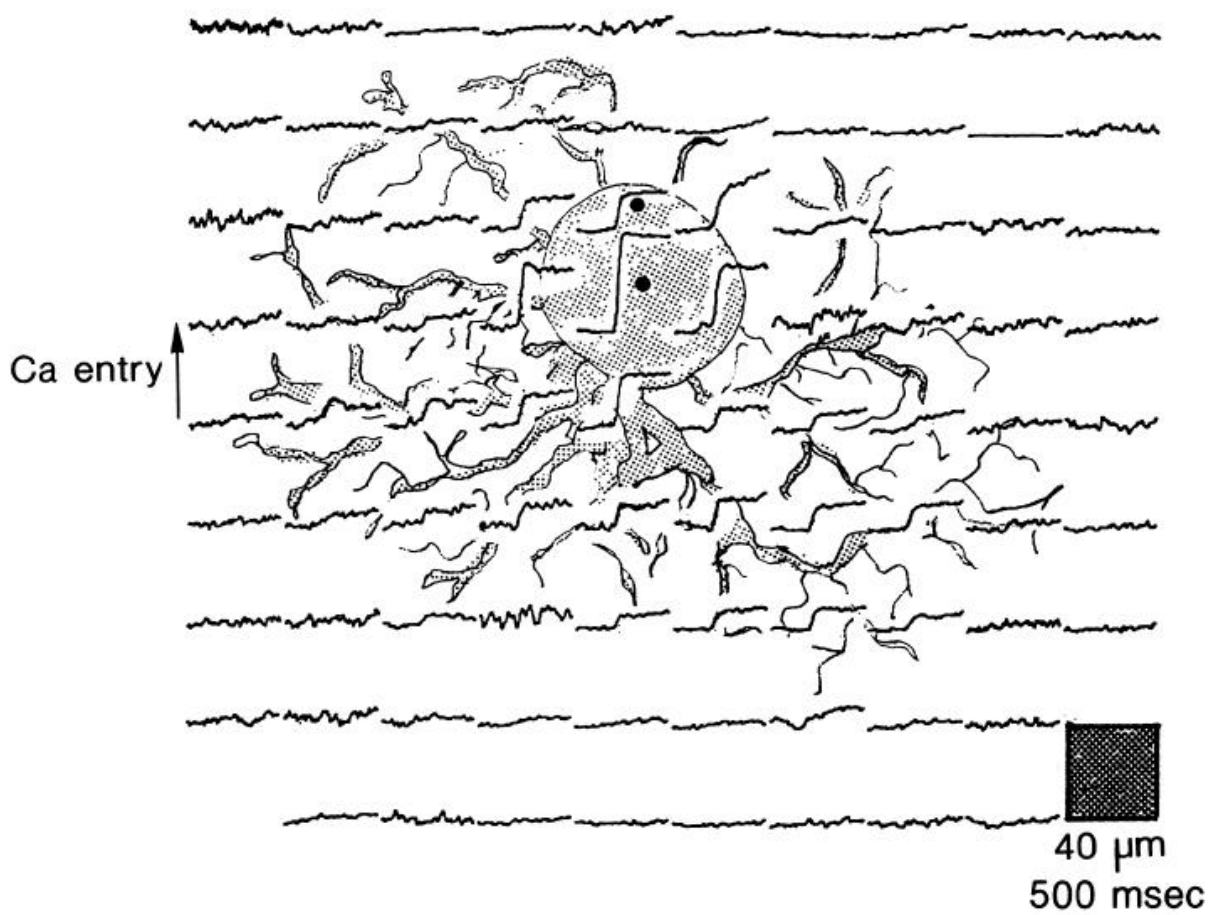

Figure 10. Changes in absorbance at $660 \mathrm{~nm}$ for 94 positions over a field containing a cultured $\mathrm{N}$ cell $(6 \mathrm{~d})$ filled with arsenazo III. Conditions similar to those in Figure 9. Average of 100 sweeps; cutoff frequency, $40 \mathrm{~Hz}$. The vertical scale for the 2 traces over the soma (traces with dots) is one-quarter the value in all other traces. Note the clear signals over most of the processes in this cell. 

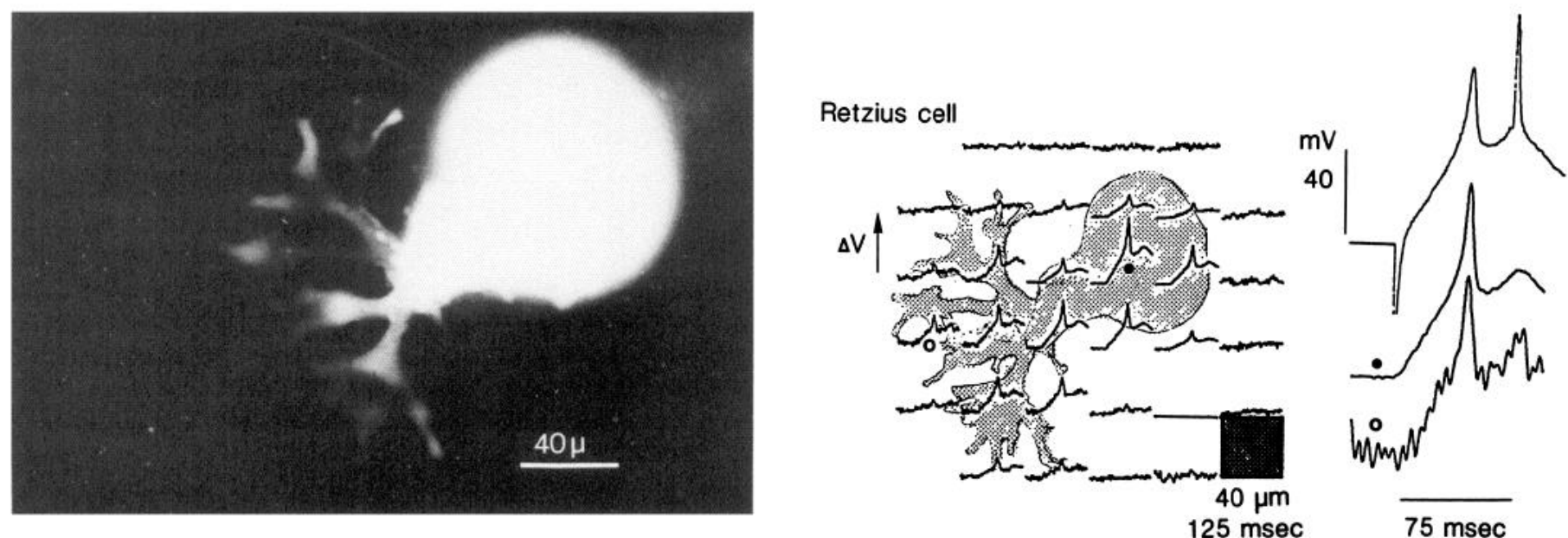

Figure 11. Changes in absorbance at $720 \mathrm{~nm}$ for 32 positions over a field containing a cultured Retzius cell ( $3 \mathrm{~d})$ that was stained with RH155. Each trace shows the signal during a $125 \mathrm{msec}$ sweep in a field $40 \times 40 \mu \mathrm{m}^{2}$ while the cell was stimulated to fire an action potential (electrical recording, top trace of inset). Average of 100 sweeps; signals low-pass-filtered at $200 \mathrm{~Hz}$. The 8 less noisy traces over the soma and axon stump are recorded at one-fifth the gain of the other traces. The 2 optical traces under the electrical record are from the soma (๑) and from the tip of the growth cone $(\mathrm{O})$. Note that the time to peak and the shape of the potential changes are the same when recorded electrically and optically at the 2 photodiode positions.

that the calcium channel density in the processes was smaller than that in the soma by the same number. If the cell became damaged during the course of this lengthy experiment, then the process voltage signals might have been relatively smaller than in the healthy cells. In this case the calcium-potential ratio would be even smaller. And this was one of the few AP cells where calcium signals were detected from the processes. This kind of experiment was not performed on $\mathrm{N}$ cells.

\section{Ca transients from leech neurons in vivo}

The uneven distribution of calcium signals from these isolated neurons prompted us to examine the distribution of calcium signals from the same cells in their normal positions within the segmental ganglia. When a Retzius cell was stimulated, similar electrical and optical responses to those in the isolated cell were detected (Fig. 14). Pairs of action potentials elicited calcium
Figure 12. Hyperpolarizing voltage transients recorded optically from 60 positions over an AP cell $(2 \mathrm{~d})$ that had been injected with arsenazo III and stained with RH155. Each trace is 125 msec long and records from a field 40 $\times 40 \mu \mathrm{m}^{2}$. Average of 200 sweeps; signals low-pass-filtered at $250 \mathrm{~Hz}$. Voltage signals were recorded from all positions over the cell. Inset, The electrical recording and 2 of the optical recordings $\left(,^{*}\right)$ had the same time course.

\section{AP cell}

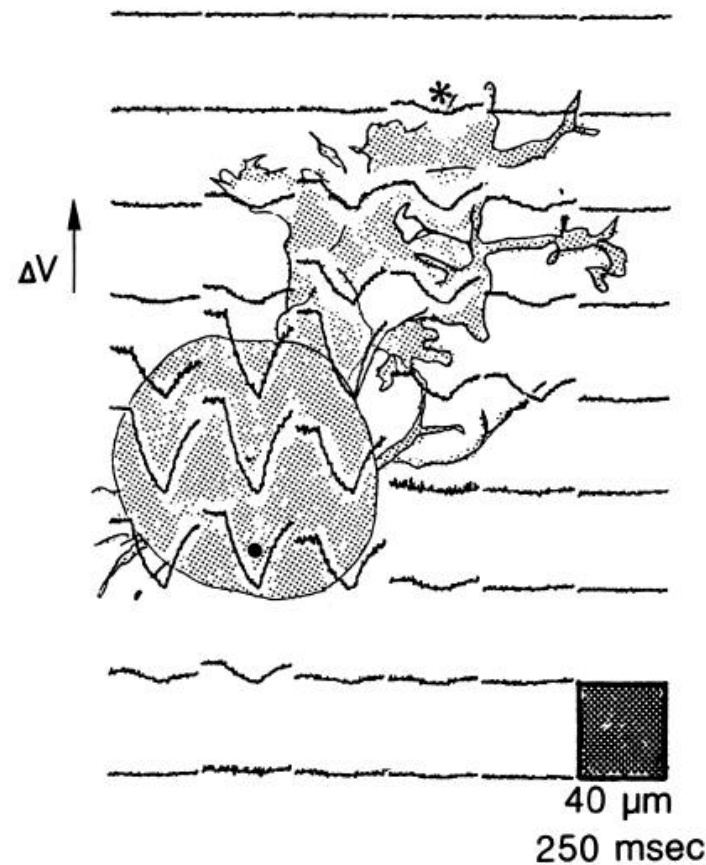




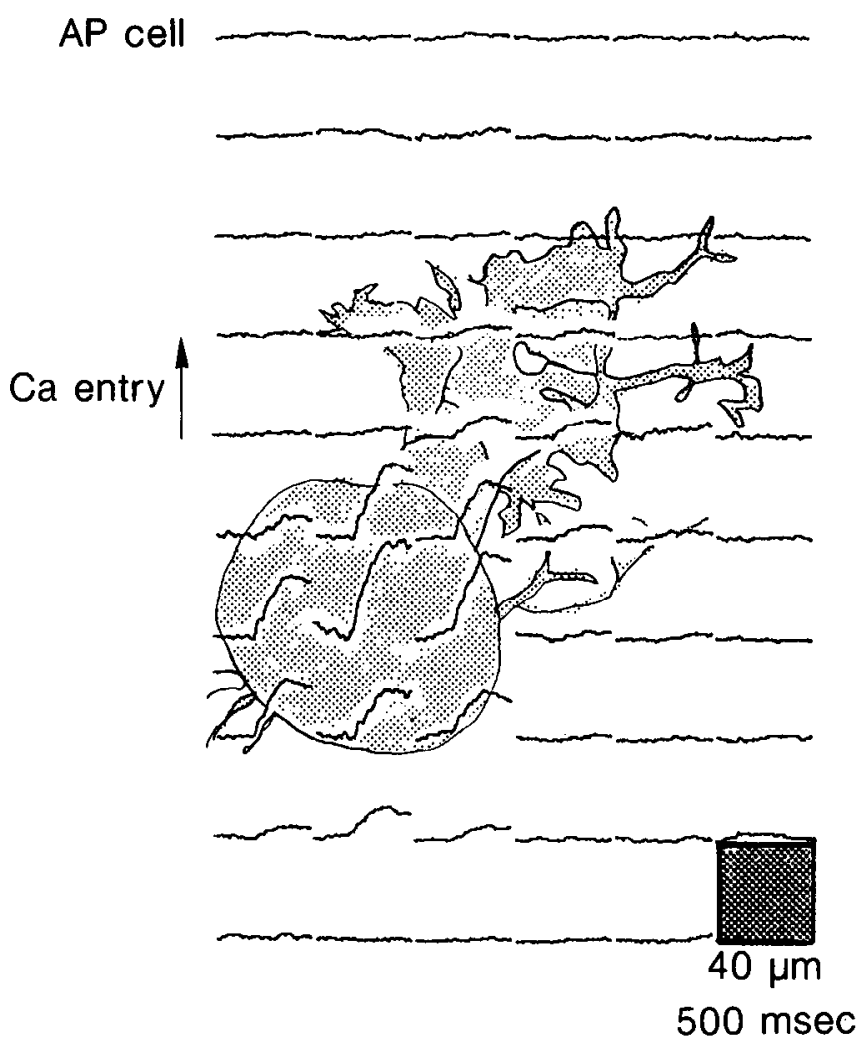

Figure 13. Calcium transients recorded from the same cell as in Figure 12. These signals were recorded before the cell was stained with RH155 and the voltage measurements were made. Average of 125 sweeps; cutoff frequency, $40 \mathrm{~Hz}$. Each trace is $500 \mathrm{msec}$. Note that the calcium signals over the processes are relatively weaker than the voltage signals.

transients that did not facilitate, and subthreshold pulses produced slowly rising, maintained signals. In addition, calcium signals were clearly detected from the neurites, even though the surface area of the Retzius cell processes in the ganglion appeared to be less than in culture. Similar signals were detected from the soma and processes of $\mathrm{N}$ cells.

\section{Discussion}

The voltage and calcium transients we recorded from cell bodies of isolated and intact leech cells resembled those recorded from other invertebrate preparations (Salzberg et al., 1973; Ahmed and Connor, 1979; Gorman and Thomas, 1980; Smith and Zucker, 1980; Ross and Krauthamer, 1984; Connor et al., 1986; Ross et al., 1986), suggesting that, qualitatively, these cells controlled calcium entry and removal in a way similar to that of these other cells. In response to action potentials, leech cells showed an increase in intracellular calcium. Larger changes were detected from N, P, and Retzius cells than from AP or T cells. This is consistent with their properties within the ganglion (Baylor and Nicholls, 1969; Jansen and Nicholls, 1973) and shows that, in this respect as well as others (Fuchs et al., 1981), the isolation and culturing procedure has not changed the membrane properties of these cells.

Neither arsenazo III nor RH155 changed the electrical properties of the cells we examined during the time we made the measurements. This was true even after a long period (1-2 hr) of incubation in the dyes. However, we noticed that several cells stained with RH1 55 began to respond with wide action potentials after a period of intense stimulation under the bright ex-

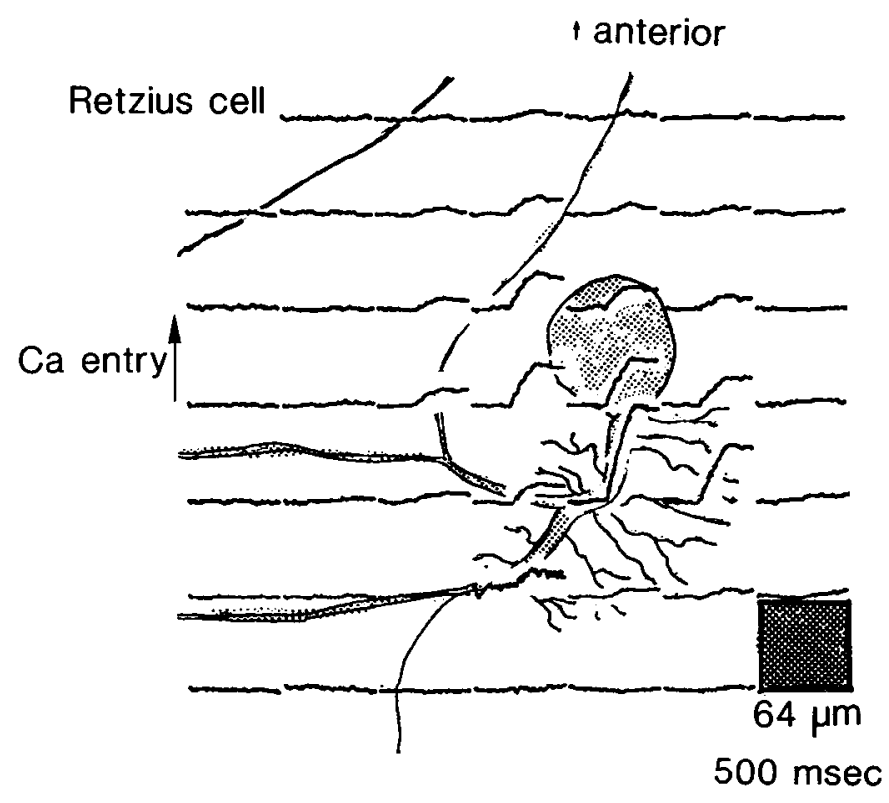

Figure 14. Calcium signals recorded from many positions over a field containing a Retzius cell in the intact ganglion. Each trace is $500 \mathrm{msec}$ long and records from an area $64 \times 64 \mu \mathrm{m}^{2}$. Average of 200 sweeps; cutoff frequency, $40 \mathrm{~Hz}$. Note the clear signals over the processes as well as over the cell body.

amining light at $720 \mathrm{~nm}$. This suggests that this dye does cause some photodynamic damage (Cohen et al., 1974), but it occurred rarely and only after a long period of stimulation and we did not examine this problem further. With arsenazo III we could record transients from a single action potential from the somata of N, P, and Retzius cells. However, clean signals or signals from the growth cones required averaging, which was also true of signals obtained using the voltage-sensitive dye. This presented no problem for the experiments attempted here, as we noticed no change in the optical or electrical responses from the cells during the averaging of over 100 trials in some experiments. Where nccessary, wc used long time intervals between trials to allow the cell to recover. It is possible that there were some subtle changes in the cell's response with time that the averaging procedure obscured. Nevertheless, it seemed that our apparatus, used in conjunction with these dyes, had sufficient sensitivity to examine a number of aspects of the problem of the control of calcium in these cells. In addition, the spatial resolution (40 $\mu \mathrm{m})$ of the photodiode array could resolve differences in the time course and amplitude of those transients in different parts of the cells.

\section{Calcium transients and synaptic facilitation}

The Retzius-P cell synapse in culture shows 2-shock facilitation and modulation of release by means of changes in the resting potential (Dietzel et al., 1986). These processes resemble those found between some cells in the intact ganglion (Muller and Nicholls, 1974; Thompson and Stent, 1976) and in other preparations (e.g., Katz and Miledi, 1965; Rahamimoff, 1968; Waziri, 1977). In every cell that we examined, the amount of calcium that entered in each impulse was the same, or differed by much less than the facilitated synaptic potential differed from the normal potential. This was true also for the Retzius cell which actually formed a synapse with a P cell (Fig. 8). Therefore, facilitation in this synapse is not likely to be due to facilitated 
calcium entry. This conclusion matches similar observations on calcium entry at the squid giant synapse (Charlton ct al., 1982). However, it is clear that the absorbance signals have not returned to baseline when the second action potential is stimulated. This observation is consistent with the "residual calcium" hypothesis of facilitation (Katz and Miledi, 1965, 1968; Parnas and Segel, 1981; Zucker and Stockbridge, 1983).

In previous experiments, Dietzel et al. (1986) showed that slow depolarizations of the Retzius cell to subthreshold potentials directly modulated the P cell membrane potential and modulated the amplitude of spike-evoked synaptic potentials. The detection of subthreshold calcium entry (Fig. 7) provides an explanation for both of these observations: the calcium entry directly evokes a tonic release of transmitter and, through the "residual calcium" mechanism, facilitates the action potentialstimulated release. The observation that holding potential did not change the spike-evoked calcium entry is also consistent with this explanation (see also Connor et al., 1986).

In our measurements of the time course and amplitude of calcium transients, we sampled a volume of the cell body. While the signals from this pixel resembled those from other positions on the cell, it is possible that at the actual point of synaptic contact the calcium transients could have a different character.

\section{Measurements of potential and channel distribution}

The Retzius and AP cells that we examined seemed to be isopotential, judging from the fact that the shapes of the voltage signals were the same in the soma and growth cones. This was true for subthreshold, hyperpolarizing, or action potentials. Because of the poor signal-to-noise ratio in the records from the growth cone, we cannot put very tight limits on this electrical equality. Nevertheless, our determination is consistent both with the cable theory predictions (I. Parnas and I. Segev, unpublished calculations) and the reversal potential measurements for iontophoretically applied ACh (Pellegrino and Simonneau, 1984). In an earlier paper (Fuchs et al., 1981) evidence was presented that action potentials might fail to propagate at branch points in some cultured $\mathrm{N}$ cells when conducted from fine processes towards the cell body. We did not examine such potentials in $\mathrm{N}$ cells with the voltage-sensitive dyes.

In cells that are isopotential, voltage measurements cannot reveal anything about the distribution of the sodium or calcium channels that are responsible for generating the action potential or where the spike is initiated. Therefore, we cannot compare our results with the experiments of Willard (1980) or Grinvald and Farber (1981), who suggested that growth cones can support calcium-dependent action potentials. Their preparations were not isopotential. Our measurements with the calcium-sensitive dye do suggest that, for Retzius and AP cells, there is a relatively high calcium channel density in the soma and axon stump compared with the newly grown processes. This was true for cells examined 2-7 $\mathrm{d}$ after isolation from the ganglion. The functional significance of this low density of channels is not clear. But we note that if the channels were distributed with uniform density over all of the surface membrane, then an action potential in the cell would cause a much higher calcium concentration change in the growth cones than in the soma because of the low volume in these flat processes. Perhaps a low channel density in the processes helps regulate the calcium level in that part of the cell, maintaining it at levels close to that in the soma.

Our estimate of the relative calcium channel distribution on the surface of these cells makes use of the fact that the absorbance change detected by each pixel is proportional to the amount of calcium cntcring the cytoplasm under that pixcl, and assumes that the proportionality constant is the same for all regions. Two groups (Mullins and Requena, 1979; Tillotson and Gorman, 1983) have suggested that the calcium-buffering power of cytoplasm is stronger near the plasma membrane than in the center of the cell, and no one has measured the buffering power of growth cones. Therefore, this assumption may not be accurate and our quantitative comparisons should be viewed with caution.

\section{Calcium and voltage measurements on the same cell}

It was relatively easy and certainly useful to make both kinds of optical measurements on the same cell. The voltage measurements confirmed the isopotentiality of the cell, which was important for determining whether calcium channels in all parts of the cell were equally activated; and the amplitudes of the voltage signals provided an estimate of the surface area in each region, which was important in normalizing the calcium signals. This kind of synergistic measurement is likely to be useful in the future, when studies are made on presynaptic terminals that release transmitter.

\section{References}

Ahmed, Z., and J. A. Connor (1979) Measurement of calcium influx under voltage clamp in molluscan neurones using the metallochromic dye arsenazo III. J. Physiol. (Lond.) 286: 61-82.

Arechiga, H., J. G. Nicholls, and W. N. Ross (1985) Optical recording of $\mathrm{Ca}$ transients following impulses in identified leech neurones in culture. J. Physiol. (Lond.) 372: 55P.

Augustine, G., M. P. Charlton, and S. J. Smith (1985) Calcium entry into voltage clamped presynaptic terminals of squid. J. Physiol. (Lond.) 367: 143-162.

Baylor, D. A., and J. G. Nicholls (1969) After effects of nerve impulses on signalling in the central nervous system of the leech. J. Physiol. (Lond.) 203: 571-589.

Baylor, S. M., W. K. Chandler, and M. W. Marshall (1982) Use of metallochromic dyes to measure changes in myoplasmic calcium during activity in frog skeletal muscle fibres. J. Physiol. (Lond.) 331: $139-$ 177.

Blaustein, M. P., and A. L. Hodgkin (1969) The effect of cyanide on the efflux of calcium from squid axons. J. Physiol. (Lond.) 200: 497527.

Bolsover, S. R., and I. Spector (1986) Measurements of calcium transients in the soma, neurite, and growth cone of single cultured neurons. J. Neurosci. 6: 1934-1940.

Charlton, M. P., S. J. Smith, and R. Zucker (1982) Role of presynaptic calcium ions and channels in synaptic facilitation and depression at the squid giant synapse. J. Physiol. (Lond.) 323: 173-193.

Chiquet, M., and S. Acklin (1986) Attachment to Con A or extracellular matrix initiates rapid sprouting by cultured leech neurons. Proc. Natl. Acad. Sci. USA 83: 6188-6192.

Cohen, L. B., and S. Lesher (1986) Optical monitoring of membrane potential: Methods of multisite measurement. In Optical Methods in Cell Physiology, P. De Weer and B. M. Salzberg, eds., pp. 71-99, Wiley, New York.

Cohen, L. B., B. M. Salzberg, H. V. Davila, W. N. Ross, D. Landowne, A. S. Waggoner, and C. H. Wang (1974) Changes in axon fluorescence during activity: Molecular probes of membrane potential. J. Membr. Biol. 19: 1-36.

Connor, J. A., R. Kretz, and E. Shapiro (1986) Calcium levels measured in a presynaptic neuron of Aplysia under conditions that modulate transmitter release. J. Physiol. (Lond.) 375: 625-642.

Dictzcl, I. D., P. Drapeau, and J. G. Nicholls (1986) Voltage dependence of 5-hydroxytryptamine release at a synapse between identified leech neurons in culture. J. Physiol. (Lond.) 372: 191-205.

Fuchs, P. A., J. G. Nicholls, and D. F. Ready (1981) Membrane properties and selective connexions of identified leech neurons in culture. J. Physiol. (Lond.) 316: 203-223.

Fuchs, P. A., L. P. Henderson, and J. G. Nicholls (1982) Chemical 
transmission between individual Retzius and sensory neurones of the leech in culture. J. Physiol. (Lond.) 323: 195-210.

Gorman, A. L. F., and M. V. Thomas (1980) Intracellular calcium accumulation during depolarization in a molluscan neurone. J. Physiol. (Lond.) 308: 259-285.

Grinvald, A. (1985) Real-time optical mapping of neuronal activity: From single growth cones to the intact mammalian brain. Annu. Rev. Neurosci. 8: 263-305.

Grinvald, A., and I. Farber (1981) Optical recording of calcium action potentials from growth cones of cultured neurons using a laser microbeam. Science 212: 1164-1169.

Grinvald, A., A. Manker, and M. Segal (1982) Visualization of the spread of electrical activity in rat hippocampal slices by voltage sensitive optical probes. J. Physiol. (Lond.) 333: 269-291.

Hamming, R. W. (1977) Digital Filters, Prentice-Hall, Englewood Cliffs, New Jersey, pp. 99-104.

Henderson, L. P. (1983) The role of 5-hydroxytryptamine as a transmitter between identified leech neurones in culture. J. Physiol. (Lond.) 339: 309-324.

Henderson, L. P., D. P. Kuffler, J. G. Nicholls, and R. J. Zhang (1983) Structural and functional analysis of synaptic transmission beween identified leech neurons in culture. J. Physiol. (Lond.) 340: 347-358.

Jansen, J. K. S., and J. G. Nicholls (1973) Conductance changes, an electrogenic pump and the hyperpolarization of leech neurones following impulses. J. Physiol. (Lond.) 229: 635-665.

Katz, B., and R. Miledi (1965) The effect of calcium on acetylcholine release from motor nerve terminals. Proc. R. Soc. Lond. [Biol.] 161: 496-503.

Katz, B., and R. Miledi (1968) The role of calcium in neuromuscular facilitation. J. Physiol. (Lond.) 195: 481-492.

Miledi, R., and I. Parker (1981) Calcium transients recorded with arsenazo III in the presynaptic terminal of the squid giant synapse. Proc. R. Soc. Lond. [Biol.] 212: 197-211.

Muller, K. J., and J. G. Nicholls (1974) Different properties of synapses between a sensory neurone and two different motor cells in the leech C.N.S. J. Phyiol. (Lond.) 238: 357-369.

Mullins, L. J., and J. Requena (1979) Calcium measurements in the periphery of an axon. J. Gen. Physiol. 74: 393-413.

Nicholls, J. G., W. N. Ross, and H. Arcchiga (1986) Membranc potential and calcium transients recorded optically from neuronal cell bodies and processes of identified leech neurons in culture. Soc. Neurosci. Abstr. 12: 370.

Parnas, H., and L. Segel (1981) A theoretical study of calcium entry in nerve terminals with application to neurotransmitter release. J. Theor. Biol. 91: 125-169.
Pellegrino, M., and M. Simonneau (1984) Distribution of receptors for acetylcholine and 5-hydroxytryptamine on identified leech neurones growing in culture. J. Physiol. (Lond.) 352: 669-684.

Rahamimoff, R. (1968) A dual effect of calcium ions on neuromuscular facilitation. I. Physiol. (Lond.) 195: 471-480.

Ross, W. N. and V. Krauthamer (1984) Optical measurements of potential changes in axons and processes of neurons of a barnacle ganglion. J. Neurosci. 4: 659-672.

Ross, W. N., L. L. Stockbridge, and N. L. Stockbridge (1986) Regional properties of calcium entry in barnacle neurons determined with arsenazo III and a photodiode array. J. Neurosci. 6: 1148-1159.

Salzberg, B. M. (1983) Optical recording of electrical activity in neurons using molecular probes. In Current Methods in Cellular Neurobiology, J. L. Barker and J. F. McKelvy, eds., pp. 139-187, Wiley, New York.

Salzberg, B. M., H. V. Davila, and L. B. Cohen (1973) Optical recording of impulses in individual neurones of an invertebrate nervous system. Nature 246: 508-509.

Smith, S. J., and R. S. Zucker (1980) Aequorin response, facilitation and intracellular calcium accumulation in molluscan neurones. $J$. Physiol. (Lond.) 300: 167-196.

Stewart, W. W. (1978) Functional connections between cells are revealed by dye-coupling with a highly fluorescent napthalimide tracer. Cell 14: 741-759.

Stinnakre, J., and L. Tauc (1973) Calcium influx in active Aplysia neurones detected by injected aequorin. Nature 242: 113-1 15 .

Stockbridge, N. L., and W. N. Ross (1984) Localized $\mathrm{Ca}^{2+}$ and calcium activated potassium conductances in terminals of a barnacle photoreceptor. Nature 309: 266-268.

Thompson, W. J., and G. S. Stent (1976) Neuronal control of heart beat in the medicinal leech. III. Synaptic relations of heart interneurons. J. Comp. Physiol. 111: 309-333.

Tillotson, D., and A. L. F. Gorman (1983) Localization of neuronal $\mathrm{Ca}^{2+}$ buffering near plasma membrane studied with different divalent cations. Cell. Mol. Neurobiol. 3: 279-310.

Waziri, R. (1977) Presynaptic electrical coupling in Aplysia; effects on postsynaptic chemical transmission. Science 195: 790-792.

Willard, A. L. (1980) Electrical excitability of outgrowing neurites of embryonic neurons in cultures of dissociated ncural platc of Xenopus laevis. J. Physiol. (Lond.) 301: 115-128.

Zucker, R. S., and N. Stockbridge (1983) Presynaptic calcium diffusion and the time-course of transmitter release and synaptic facilitation at the squid giant synapse. J. Neurosci. 3: 1263-1269. 